\title{
Analysis of performance indicators of investment and construction sector of the Russian Federation in the conditions of economic crisis
}

\author{
Sergei Beliakov ${ }^{1, *}$, Yulia Boriskina ${ }^{1}$, and Mikhail Gnevanov ${ }^{1}$ \\ ${ }^{1}$ Moscow State University of Civil Engineering, Yaroslavskoe shosse, 26, Moscow, 129337, Russia
}

\begin{abstract}
The article analyzes the performance indicators of the investment and construction sector in the Russian Federation in the conditions of the crisis, the main trends of development of this sphere in the period from 2008 to 2016 in the projects of construction of residential and commercial real estate are considered. It was noted that during this period there has been a significant growth in construction and commissioning of buildings, while consumer demand for both residential and commercial real estate is declining. Also considered are the main participants of the housing construction market, analyzed the specifics of mortgage lending in this period. Among the negative prospects for the development of the industry, a reduction in the volume of input, freezing or reformatting of projects was noted.
\end{abstract}

\section{Introduction}

The investment and construction sphere plays a significant role in the economy of any country for a number of reasons:

- the organization of a large number of jobs, which increases the level of employment of the population;

- the level of quality of life of the population directly depends on the volume of built square meters of housing;

- the construction industry plays the role of a locomotive in relation to a number of branches of the economy (consulting, advertising spheres, production of building materials, leasing sphere) [1].

- in large cities, investment and construction companies form a living environment and can influence the attractiveness of the territories, increasing the number of social, entertainment and transport infrastructure.

Against the background of global economic and political processes, the Russian economy faced crises that had impulses in 2008 and 2014, as a result of which a number of changes occurred in the country's sectors, investors' interests, strategic plans of the companies, financing conditions. At the same time, the investment and construction sector, due to its

\footnotetext{
* Corresponding author: serj-bel@yandex.ru
} 
large scale and long-term period of project implementation, has fewer opportunities for rapid reaction and restructuring in the short term. Let us consider in more detail how the development of the industry took place precisely in this difficult period.

\section{Investment and construction sector performance indicators}

In 2014, there was a decrease in the amount of work performed by the type of activity "Construction": the decrease amounted to $4.5 \%$ or 5.9 trillion rubles in relation to 2013 . A decrease in the share of investment in construction in the total volume of investments in fixed assets was noted: its share was less than 3\%. In the GDP structure construction accounted for about $8.3 \%$. During the period of 2013, Russian construction companies commissioned residential buildings with a total area of more than 101 million square meters (with apartments of more than 80 million square meters) and more than 30 million square meters non-residential premises, of which about $30 \%$ accounted for commercial buildings, the rest of the buildings are industrial and social infrastructure [2].

In 2015, according to Rosstat, the amount of work by type of activity "Construction" amounted to 6148.4 billion rubles in actual prices, and its physical volume decreased by $4.8 \%$ compared to last year. In 2014 there was a decrease of $2.3 \%$ compared to the previous year (Table 1) [3].

Table 1.The amount of works performed by the type of economic activity "Construction".

\begin{tabular}{|c|c|c|c|}
\hline & Billion RUB, in & \multicolumn{2}{|c|}{ In percent, at constant prices } \\
\cline { 3 - 4 } & current prices & to the previous year & to 1990 \\
\hline 2008 & 4528.1 & 112.8 & 90.8 \\
\hline 2009 & 3998.3 & 86.8 & 78.9 \\
\hline 2010 & 4454.1 & 105.0 & 82.8 \\
\hline 2011 & 5140.3 & 105.1 & 87.0 \\
\hline 2012 & 5714.1 & 102.5 & 89.2 \\
\hline 2013 & 6019.5 & 100.1 & 89.3 \\
\hline 2014 & 6125.2 & 97.7 & 87.3 \\
\hline 2015 & 6148.4 & 95.2 & 83.1 \\
\hline
\end{tabular}

In 2015 , the construction industry lagged by the volume of production from the indicator of 1990 by $18.9 \%$ in a comparable assessment. At the same time, a record number of square meters of housing was put into operation, which amounted to 85.3 million square meters the total area, which is $1.4 \%$ more than in 2014. This is almost 3 times higher than in 2000, when the minimum number of housing units (30.3 million square meters) was introduced in 25 years [4]. At the end of 2015, housing commissioning at 21.2 million square meters exceeded the pre-crisis maximum of 2008. The implementation of such a number of square meters was in part contributed to the devaluation of the ruble at the end of 2014, which caused an additional, often frenzied, demand of the population for real estate, seeking to save its savings. However, the inertial growth of housing construction, which continued in the first half of 2015, against the background of a decrease in the effective demand of the population led to a redundancy of new buildings in the housing market [4].

From 2005 to 2014 the average size of living space in Russia per person has increased not significantly: from 21 to 24 square meters, the level of provision of Russians with housing remained insufficient in comparison with the developed countries. It was only 1.5 times higher than in recent years in the USSR and 3 times lower than the level of housing provision for US citizens (in the US - 70 square meters per person, in Germany and France - 39, in Poland - 25) [4]. 
At the end of 2015, the share of housing construction costs in the total volume of investment in fixed assets in Russia was about $12.2 \%$ (compared to $15.5 \%$ in the United States, $23 \%$ in the UK, $29.8 \%$ in Germany). The industry employed about 5.8 million people, the specific weight of employed in construction in the total number of employed in the economy was $8.4 \%$ [1].

In total, there were about 235000 operating construction companies in Russia, out of which only more than 250 people worked in 1500 organizations [2].

Table 2.The number of construction companies operating in Russia in 2008-2015.

\begin{tabular}{|c|c|c|c|c|c|c|c|c|}
\hline & 2008 & 2009 & 2010 & 2011 & 2012 & 2013 & 2014 & 2015 \\
\hline Total & 155036 & 175817 & 196234 & 209185 & 205075 & 217961 & 226838 & 235351 \\
\hline $\begin{array}{l}\text { Including } \\
\text { by forms } \\
\text { of } \\
\text { ownership: }\end{array}$ & & & & & & & & \\
\hline State & 1346 & 1249 & 1203 & 1108 & 950 & 879 & 818 & 832 \\
\hline Municipal & 601 & 512 & 530 & 499 & 449 & 403 & 395 & 461 \\
\hline Private & 150317 & 171291 & 192165 & 205416 & 201274 & 214055 & 223022 & 233140 \\
\hline $\begin{array}{l}\text { Combined } \\
\text { Russian }\end{array}$ & 1076 & 864 & 775 & 605 & 606 & 522 & 405 & 293 \\
\hline Other & 1696 & 1901 & 1561 & 1557 & 1796 & 2102 & 2198 & 625 \\
\hline
\end{tabular}

However, the state of the economy has a great influence on the development of the investment and construction sector. So, the construction in the Russian Federation actually turned out in the conditions of the crisis in the second half of 2008, during the indicated period the stagnation of investment processes as a whole became obvious. Factors that limited the production activity of construction organizations, as determined by Rosstat, are shown in Figure 1.

\section{The main factors that limit the production activity of construction companies}

(according to sample inquiry)

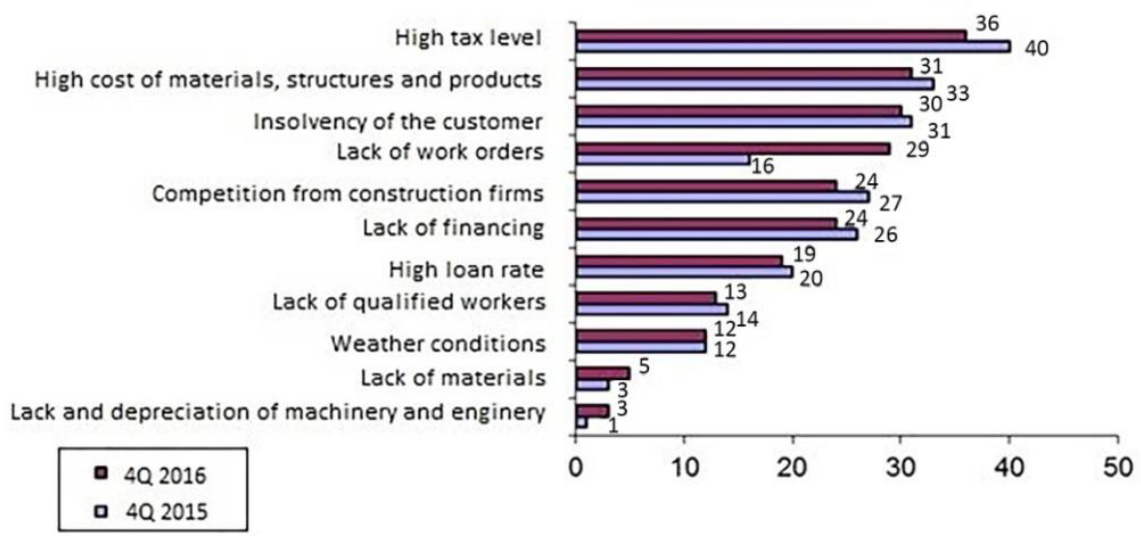

Fig. 1.The factors restricting production activity of construction organizations. 
The main factor limiting the production activity of construction organizations was a high level of taxes (in 2016, it accounted for 36\%, in $2015-40 \%$ ). Also high was the weight of the factors "High cost of materials, structures and products" (31\% in 2016 and $33 \%$ in 2015) and "Insolvency of customers" (30\% in 2016 and 30\% in 2015). Also among these factors were the lack of orders for work, competition from construction companies, lack of financing, etc. According to major market participants, these factors also adversely affected the development of the construction industry [5].

\section{The leading construction companies}

The leading positions in the industry were occupied by vertically integrated companies combining development and rendering of construction contracting services, production of construction materials and structures. The largest construction holdings included SU-155, PIK Group, LSR Group, Morton, FSK Leader, etc. These companies implemented large development projects in the Moscow region, St. Petersburg and the Leningrad region. Recently, there has been an increase in the presence of St. Petersburg companies in the Moscow market, while large Moscow developers have shown their interest in St. Petersburg and the Leningrad region, as well as in other regions with dynamic indicators of socio-economic development (in particular, in the Kaluga region) [6].

The largest participant of the market of housing construction of the Moscow region in 2015g. Was the PIK Group, which earlier in the same year included the company Morton. In 2015, the PIK Group put into operation more than 1 million square meters of housing, and the company's revenue amounted to more than 62 billion rubles. The total current portfolio of projects included more than 7.8 million square meters of housing. The company owned its own house-building plant in the suburbs, which had a capacity of more than 450 thousand square meters of housing and implemented in conjunction with Rosnano. Estimates of the company's top management indicate that the debt of Morton amounted to 19 billion rubles at the end of 2014, while in 2015 the company managed to reduce its loan portfolio by an average of $32 \%$ [7].

Another major market participant was the LSR Group company (St. Petersburg). This company was able to gain a foothold in the real estate market in Moscow and the Moscow region. The revenue of LSR Group in 2014 increased by 53\% to 92.3 billion rubles, and in 2015 the company's revenue increased by only $15 \%$. A landmark project of the group in Moscow is the redevelopment of the territory of the former ZIL auto plant [8].

A significant place was occupied also by the company-developer - GC Pioneer, which in 2015 was able to increase revenues in comparison with 2014 by $36.8 \%$. The company commissioned 216 thousand square meters of real estate in Moscow and St. Petersburg. In the future, it is planned to hand over more than 250 thousand square meters [6].

The management of the company announced the construction of new lines in the projects of integrated development. The largest promising project of the company is the construction of a multifunctional complex worth 11 billion rubles in the Mitinomicro district (Moscow). Also, the developer is actively developing its own network of apart-hotels - including, by selling a franchise. The company is considering the possibility of issuing bonds in order to finance new projects. Partner of GC Pioneer is PJSC Sberbank of Russia, which finances the construction of a number of projects: for the GC Pioneer a credit line with a volume of 2.5 billion rubles has been opened in this bank to finance the construction of a residential complex in St. Petersburg [9].

One of the largest and fastest growing company in the housing market of the capital was the Moscow construction company FSK Leader. In 2014 the company sold real estate 50\% more than in the previous year, in 2015 the sales volume was increased by $35 \%$. Among the sold real estate - apartments, commercial premises and parking places in the parking lots. 
The company actively expanded its business geography: in addition to the sites in Moscow and the Moscow region, it implemented a number of large projects in the Kaluga and Leningrad regions [6].

\section{Housing construction}

It should be noted that the volumes of housing introduced in Russia grew. According to Rosstat, in 2014, Russian construction companies put into operation more than 1 million apartments with a total area of about 80.8 million square meters, by $16.8 \%$ more than a year earlier. In 2015, the volume of commissioned housing amounted to 1.2 million apartments. However, it should be noted that the development of housing construction took place in isolation from related industries: the growth of problems that were caused by the economic recession and instability of the financial market was ignored [5].

Developers, although less active than in previous years, but laid new projects. The FSK Leader plans to invest in the construction of a residential complex in the Leningrad region more than 7 billion rubles. The company City - XXI Century in 2015 was purchased several new sites, which are planned to build housing [10].

The main product, which is offered by construction companies, are apartment houses with a large share of compact, compact apartments, the area of which is from 19-25 square meters. In the structure of the supply of the market for new buildings, a large share is occupied by projects on the outskirts of large cities. Most often, construction is carried out on free plots of land that do not always have a social and transport infrastructure. The undisputed leader in terms of multifamily construction was the Moscow region, where, by the end of 2015, more than 8.9 million square meters of housing had been commissioned. The Krasnodar Region (4.7 million square meters), Moscow (3.3 million square meters), St. Petersburg (3.2 million square meters) and the Republic of Bashkortostan (3.2 million square meters) entered the top five. Increasing volumes of construction acted as a factor restraining the growth of housing prices in the primary and secondary markets. Thus, the company IRN.ru data testified that in Moscow real estate prices adjusted for inflation did not show growth for the last nine years, and the average cost of new buildings in St. Petersburg increased by less than $10 \%$ [6].

More than half of all investments in Russia accounted for the construction of residential premises (15\% of all investments in 2015) and non-residential buildings and structures $(41 \%)$, while the share of construction of residential buildings has been growing steadily since 2010 [2].

Table 3. The pace of housing construction in 2008-2015 [2].

\begin{tabular}{|c|c|c|c|}
\hline \multirow{2}{*}{ Years } & \multicolumn{3}{|c|}{ Builthousing } \\
\cline { 2 - 4 } & $\begin{array}{c}\text { million square meters } \\
\text { of total area }\end{array}$ & $\begin{array}{c}\text { in \% to the previous } \\
\text { year }\end{array}$ & $\begin{array}{c}\text { in \% to the total } \\
\text { volume of } \\
\text { construction of } \\
\text { buildings }\end{array}$ \\
\hline 2008 & 64.1 & 104.6 & 62.5 \\
\hline 2009 & 59.9 & 93.5 & 63.0 \\
\hline 2010 & 58.4 & 97.6 & 63.9 \\
\hline 2011 & 62.3 & 106.6 & 63.0 \\
\hline 2012 & 65.7 & 105.6 & 59.6 \\
\hline 2013 & 70.5 & 107.2 & 59.8 \\
\hline 2014 & 84.2 & 118.2 & 60.7 \\
\hline 2015 & 85.3 & 101.4 & 61.2 \\
\hline
\end{tabular}




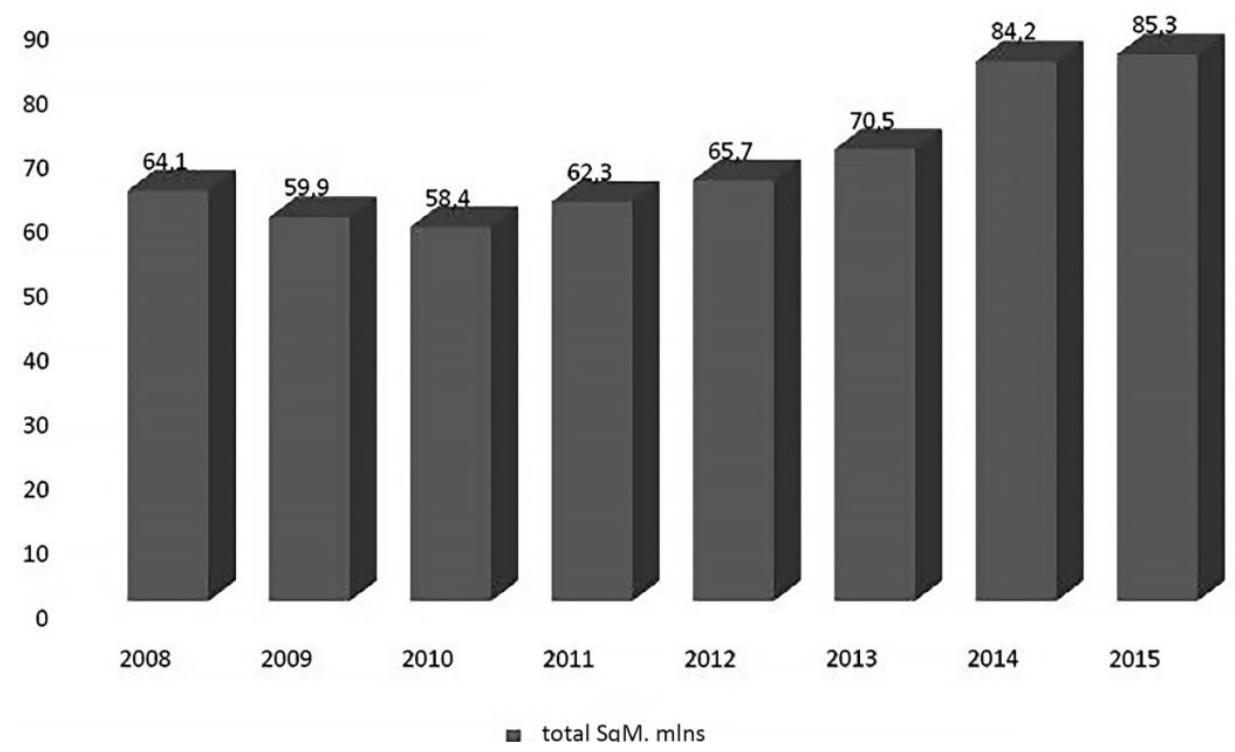

Fig. 2.The pace of housing construction in 2008-2015.

\section{Financial support and mortage}

The investment boom that took place in the market of housing construction, provided expansion of corporate and mortgage lending. In 2013, the growth of the mortgage market was noted, on average, by $30 \%$, which caused a decrease in interest rates, and more than $60 \%$ of newly built housing was purchased on mortgage terms [12].

Table 4. The number of mortgage loans in rubles and in foreign currency, thousand units (20082015).

\begin{tabular}{|c|c|c|c|c|c|c|c|c|}
\hline Figure & $\mathbf{2 0 0 8}$ & $\mathbf{2 0 0 9}$ & $\mathbf{2 0 1 0}$ & $\mathbf{2 0 1 1}$ & $\mathbf{2 0 1 2}$ & $\mathbf{2 0 1 3}$ & $\mathbf{2 0 1 4}$ & $\mathbf{2 0 1 5}$ \\
\hline $\begin{array}{c}\text { The number } \\
\text { of loans in } \\
\text { rubles } \\
\text { thousand } \\
\text { units. }\end{array}$ & 489 & 176 & 392 & 588 & 739 & 878 & 1059 & 707 \\
\hline $\begin{array}{c}\text { The number } \\
\text { of loans in } \\
\text { foreign } \\
\text { currency, } \\
\text { thousand } \\
\text { units }\end{array}$ & 18.3 & 2.2 & 3.4 & 3.1 & 1.8 & 2.0 & 0.81 & 0.13 \\
\hline $\begin{array}{c}\text { Average } \\
\text { exchange } \\
\text { rate, rubles } \\
\text { per USD }\end{array}$ & 24.9 & 31.8 & 30.4 & 29.4 & 31.1 & 31.9 & 38.4 & 61.3 \\
\hline
\end{tabular}

In 2013, for the construction of buildings and facilities, banks issued a significant amount of loans, amounting to about 1.7 trillion rubles, and the volume of financing increased by $23 \%$. The main creditors were large banks, as well as banks with state participation. The market, fueled by credit money, began to grow rapidly: the demand for housing under construction increased, and the supply of new buildings expanded [13]. During the first half of 2014, developers made active speculation of the high volatility of 
the foreign exchange market and the instability of banks and suggested that depositors of credit institutions convert their savings into square meters.

In the second half of 2015, the situation changed dramatically. After the Central Bank raised the discount rate and the ruble collapsed, banks began to inflate mortgage rates from $11-12 \%$ per annum to $15-20 \%$ per annum, the conditions for issuing loans were tightened (the minimum initial deposit increased, programs that allowed To issue a loan in accordance with a reduced package of documents, etc.). Devaluation resulted in a sharp increase in the cost of servicing loans for borrowers who borrowed in foreign currency. [14] All of the foregoing predetermined a slowdown in the growth of the mortgage market: from $40-50 \%$ to $13 \%$ per month. If, as a result of 2014 , more than 1 million mortgage loans were issued for a total of 1.76 trillion rubles, which is 1.23 times the level of 2013 in quantitative terms and 1.3 in monetary terms, at the beginning of 2015 the volume Issued mortgage loans was less than the same period last year by $22 \%$. The average interest rate on loans increased to $14.7 \%$ per annum, which entailed an outflow of customers [5].

The real estate market participants attempted to break the negative trend by introducing surrogate financing schemes (long-term installments, long-term leases with the right of subsequent repurchase, etc.), but these proposals did not become attractive to the mass buyer who lost the credit lever [15].

Tendencies to decline began to be noted in corporate lending. Liquidity problems forced banks to take a wait-and-see position, shortening the terms of lending and increasing rates. The volume of loans for construction of buildings and structures as a result of 2014 decreased by $19 \%$, and by the end of 2015 - by $21 \%$, which caused a loss of balance in companies with high credit load. So, SU-155 brought dozens of lawsuits by banks Globex, VTB, Bank of Moscow and Rosbank, Sberbank. The creditors submitted claims to the Nizhny Novgorod holding company DSK-NN, implying the need to pay debts for taxes and salaries, as well as for non-payments to counterparties. To save companies that were recognized as backbone in the previous crisis, the government launched a program to subsidize the interest rate on loans that were issued for the purchase of housing under construction. To this end, the budget allocated 20 billion rubles to compensate for the difference between the funding rate for the bank and the rate for the final borrower, which should not exceed $12 \%$. These subsidized loans were limited, and banks within the program could issue loans for 400 billion rubles [2].

According to some forecasts, against the background of a decline in household incomes and a possible increase in unemployment, the volume of mortgage issuance will decrease. Compression of the mortgage market, even in substantially smaller proportions, will create problems for both developers and producers of building materials. Some market players, fearing the development of the situation in this scenario, began to slow down. So far the only encouraging signal for the industry has been the launch of a program to subsidize mortgage rates for the purchase of housing under construction. However, according to expert estimates, the mechanism of artificial increase in the availability of credit will provide developers with less than $10 \%$ of the total funding requirement. At the same time, further replication of this scheme is fraught with destabilization of the mortgage market due to deterioration in the quality of the loan portfolio [17].

The annual volume of budget financing of housing transactions (according to various estimates, it is about the amount of about 450-600 billion rubles), which were allocated in the framework of federal programs (certificates, subsidies, etc.), also failed to compensate for the outflow of market demand.

\section{Commercial Real Estate}

Unlike the housing construction market, which received assistance from the state during the 
crisis, it was not necessary to count on the commercial real estate market. Over the past few years, this market has developed against general economic trends and, in the end, has reached a dead end. The data of the company Cushman \& Wakefield indicate that over the last two years in Moscow, a record number of offices - 1.4 million square meters - has been put into operation in the last 5 years (54 buildings), construction of another 2.3 million square meters is also underway of office real estate. For office real estate the picture is the same: in 2014, Moscow and regions introduced more than 2.1 million square meters of retail space in 60 malls. At the same time, consulting companies note that out of this number of retail space, 14 new shopping centers with a total sales area of square meters opened in Moscow. Among them - the largest in Europe mall - Aviapark, Mari in the metropolitan area of Marino with a total area of 138 thousand square meters The growth of the warehouse property market in 2014-2015 amounted to 2.65 million square meters, of which about 1.65 million are located in Moscow [2].

Quite intensive construction of commercial real estate was also noted in the regions. So, in Perm have commissioned more than 160 thousand square meters retail and office real estate, in Yekaterinburg in the past year, built 9 business centers with a total area of more than 112 thousand square meters. But Moscow remained the market leader.

Table 5.The volume of commercial real estate in Moscow, thousand sq.m.

\begin{tabular}{|c|c|c|c|}
\hline Figure & $\mathbf{2 0 1 3}$ & $\mathbf{2 0 1 4}$ & $\mathbf{2 0 1 5}$ \\
\hline Offices & 590 & 880 & 1390 \\
\hline SEC & 185 & 214 & 630 \\
\hline Warehouses & 664 & 892 & 1620 \\
\hline
\end{tabular}

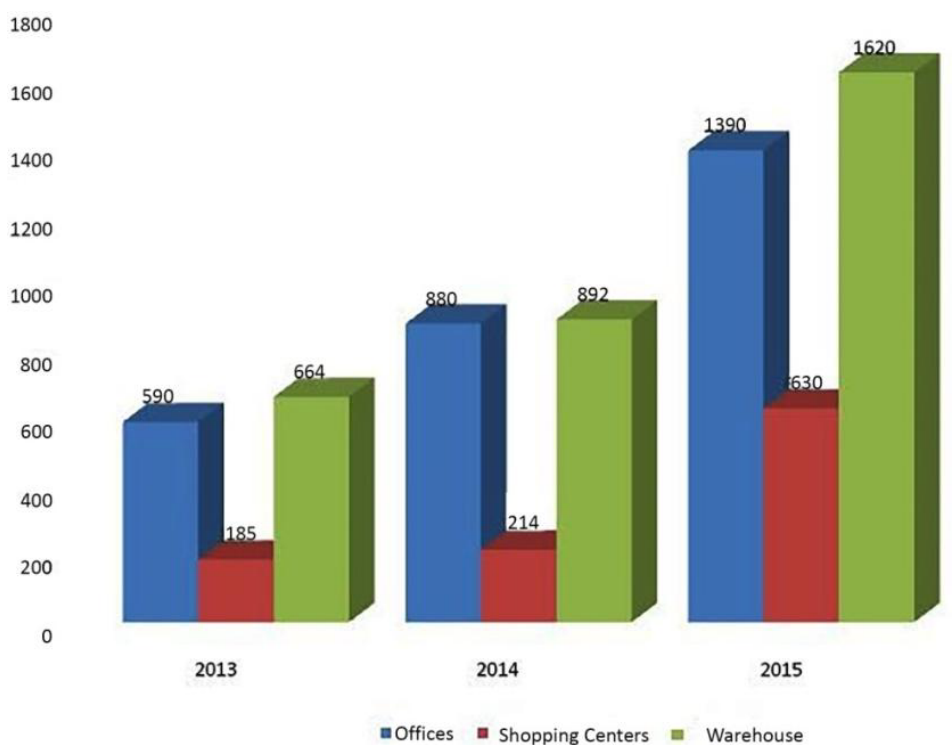

Fig. 3. The volume of commercial real estate in Moscow, thousand sq.m.

The increase in the commissioning of commercial real estate facilities cannot be regarded today as a positive factor: a significant part of offices, shopping centers and warehouses have not been in demand so far, because of financial and political instability, companies have reduced turnover, cost optimization, staff reduction. So the companies were not located to the crossings. The most "overstocked" office, in which were found to be unclaimed about $17-18 \%$ of the area. Evaluation of the Cushman \& Wakefield indicates that in 2015, 19.2\% less offices were in demand than in the previous year. Empty rooms and shopping centers, which is the reason for reducing rental rates [5]. 
The main reason for the growth in the entry of objects against the background of a general microeconomic downturn was that companies had to complete and introduce objects that were already at the implementation stage. The peak of this input just happened in 2015. And already in 2016 we see a tendency to reduce the input of space, the company reduced the development of new projects in the field of commercial real estate. This trend will continue until the demand for commercial space is restored [18].
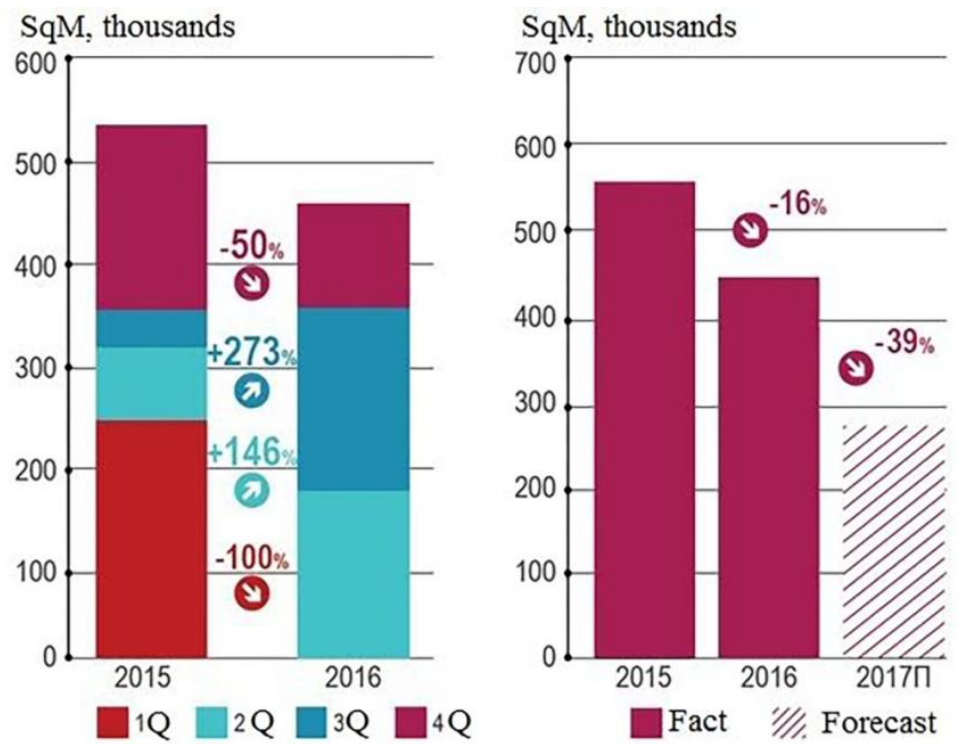

Fig. 4. The volume of commissioned retail space in 2016.

\section{Conclusion}

For the period under review, the growth rate of the construction industry fell for the first time in 2009, after which it grew again, as many investors and developers thought that the crisis was over, but since 2014, again there was a decrease. Among the factors negatively affecting development in 2015-2016, the participants in the construction industry noted the problem of obtaining financing and low demand [19].

Against the background of crisis phenomena in the industry as a whole, the sphere of housing construction showed positive dynamics. In 2015, a record number of square meters of housing was put into operation, which amounted to 85.3 million square meters of the total area. In many respects this was due to the fact that in 2014, Real estate was a means of saving savings and demand even for a while increased, as well as the introduction of the state program to support mortgages in new buildings, which helped support the demand for housing [20]. However, the inertial growth in housing construction, which continued in the first half of 2015, amid a decline in household incomes and effective demand, led to a redundancy of new buildings in the housing market, developers had to dramatically reformat the projects. Among the features it is possible to single out a significantly increased share of budget small-sized apartments and studios on the market, offers of installments for payment from developers.

Commercial real estate in 2015 also became a record year of commissioning of facilities, in particular shopping centres. Developers, not timely respond to the signals from the economy in 2008 and 2009 were forced to complete the projects, despite the obvious drop in demand and rental rates. In 2016 there is a decrease in volume of commissioning 
and initiating new projects. If the housing market could count on help and attention from the state, the participants of the commercial real estate market had to deal with the crisis of overproduction and poor market conditions alone: to reduce the volume of input, freeze, or reformat your projects and adhere to flexible pricing policy[21].

Overall, it can be noted that despite temporary difficulties with the financing and falling demand for real estate, the largest real estate developers continue to evolve, adapting to market conditions: the market place mergers and acquisitions of companies attending the launch and implementation of complex projects, reduced the planned volumes of construction and increases the time of implementation of projects, develop new costeffective formats that meet modern consumer demand [22].

In commercial real estate in 2015 it also became a year of record-setting of objects, in particular shopping centers. Developers who did not respond in time to the signals of the economy in 2008-2009, they were forced to finish the projects they started, despite the obvious drop in demand and rental rates. Since 2016 there is a decrease in the amount of input and initiation of new projects. If the housing market could rely on help and attention from the state, then the commercial real estate market participants had to deal with the crisis of overproduction and bad situation on their own: reduce input, freeze or reformat projects and adhere to a flexible pricing policy [21].

In general, it can be noted that in spite of temporary difficulties with financing and falling demand for real estate, the largest developers continue to develop, adjusting to market conditions: mergers and acquisitions of companies take place on the market, complex projects are launched and implemented, the volume of planned construction is reduced and The time of project implementation increases, new economical formats are created that meet the current demand of the consumer [22].

\section{References}

1. V.V. Kushchenko,Development. The modern concept of property (Norma, Moscow, 2012)

2. http://www.infoline.spb.ru/issledovanie-stroitelnogo-rynka.htm

3. http://www.gks.ru/

4. National Rating Agency,Market construction and real estate(2014)

5. http://id-marketing.ru/about/uslugi/obzori-rinka-id-marketing/analiz-stroitelnogo-rinka

6. Bulletin of the socio-economic crisis in Russia5, 39(2015)

7. On the current situation in the Russian economy in the I quarter of 2016 (Moscow, 2016)

8. http://www.jll.ru/russia/ru-ru/research/232/overview of the market-trading-estateMOSCOW-4-sq-2016

9. V.Kankhva, S.Uvarova, S.Belyaeva, Procedia Engineering 165, 1046-1051 (2016)

10. G. Guselbaeva, O. Pachkova, Procedia Economics and Finance 27, 501-506 (2015)

11. T. G.Viciu, M.Toma, D. L.Ţâmpu, Procedia Economics and Finance 6, 161-168 (2013)

12. D. Medvedev, Russian Journal of Economics 2, 327-348 (2016)

13. V.Kankhva, S.Uvarova, S.Belyaeva, Procedia Engineering 165, 1046-1051 (2016)

14. J.Vertakova, L.Shirokova, M.Bedakova,Procedia Economics and Finance14, 644649(2014)

15. T. D. Crises, Technological Forecasting and Social Change 77, 739-761(2010) 
16. G.P. Boretos,Technological Forecasting and Social Change 76, 316-326(2009)

17. T.G.Viciu, M.Toma, D.L.Ţâmpu,Procedia Economics and Finance 6, 161-168(2013)

18. L.Klapper, A. Lusardi, G.A. Panos,Journal of Banking \& Finance 37, 3904-3923(2013)

19. I.A. Kirshin, M.V. Maleev, O.V. Pachkova, Procedia Economics and Finance 14, 320325(2014)

20. I.Lukmanova, N.Yaskova,Procedia Engineering 165, 1293-1299(2016)

21. E.K. Chirkunova, E.E. Kireeva, A.D. Kornilova, J.S. Pschenichnikova,Procedia Engineering 153, 112-117(2016)

22. E.V.Sitnikova, I.N.Tretyakova, T.S.Kolmykova,Procedia Economics and Finance 24, 659-665(2015) 